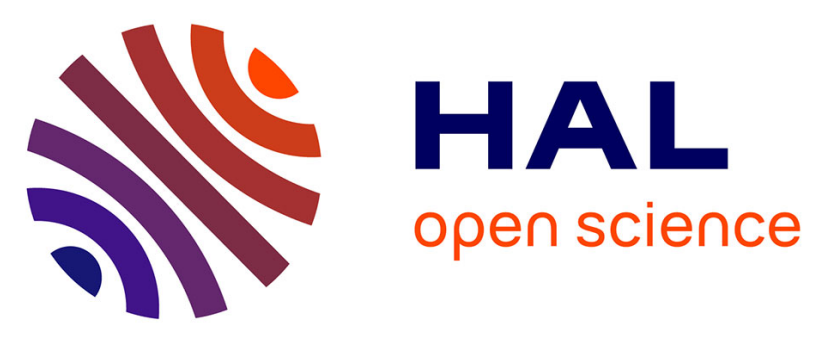

\title{
Comment on: Functional MUC4 suppress epithelial-mesenchymal transition in lung adenocarcinoma metastasis. Gao L, Liu J, Zhang B, Zhang H, Wang D, Zhang T, Liu Y, Wang C. Tumour Biol. 2013, in press
}

Nicolas Jonckheere, Isabelle van Seuningen

\section{To cite this version:}

Nicolas Jonckheere, Isabelle van Seuningen. Comment on: Functional MUC4 suppress epithelialmesenchymal transition in lung adenocarcinoma metastasis. Gao L, Liu J, Zhang B, Zhang H, Wang D, Zhang T, Liu Y, Wang C. Tumour Biol. 2013, in press. Tumor Biology, 2014, 35 (4), pp.3941-3942. 10.1007/s13277-013-1390-y . inserm-02371186

\section{HAL Id: inserm-02371186 https://www.hal.inserm.fr/inserm-02371186}

Submitted on 19 Nov 2019

HAL is a multi-disciplinary open access archive for the deposit and dissemination of scientific research documents, whether they are published or not. The documents may come from teaching and research institutions in France or abroad, or from public or private research centers.
L'archive ouverte pluridisciplinaire HAL, est destinée au dépôt et à la diffusion de documents scientifiques de niveau recherche, publiés ou non, émanant des établissements d'enseignement et de recherche français ou étrangers, des laboratoires publics ou privés. 


\section{Comment on:}

Functional MUC4 suppress epithelial-mesenchymal transition in lung adenocarcinoma metastasis. Gao L, Liu J, Zhang B, Zhang H, Wang D, Zhang T, Liu Y, Wang C. Tumour Biol. 2013 in press

Nicolas Jonckheere $^{1,2,3}$ and Isabelle Van Seuningen ${ }^{1,2,3}$

1 Inserm, UMR837, Jean Pierre Aubert Research Center, Team \#5 “Mucins, epithelial differentiation and carcinogenesis”, rue Polonovski, 59045 Lille Cedex, France

${ }^{2}$ Université Lille Nord de France, 1 Place de Verdun, 59045 Lille cedex, France

${ }^{3}$ Centre Hospitalier Régional et Universitaire de Lille, Place de Verdun, 59037 Lille cedex, France.

Corresponding author : Dr Nicolas Jonckheere, Inserm UMR837/JPARC, rue Polonovski, 59045 Lille Cedex, France, Phone: +33 3202988 76, Fax: +33 3205385 62, E-Mail: nicolas.jonckheere@inserm.fr

Keywords: MUC4; oncomucin; lung adenocarcinoma; epithelial mesenchymal transition

To the editor,

Gao and collaborators have investigated the role of MUC4 in lung cancer and have concluded that loss of MUC4 results in epithelial mesenchymal transition via beta catenin nuclear translocation and that MUC4 expression is correlated with a risk of lymph node metastasis in a 20 lung adenocarcinoma patients cohort [1]. This surprising analysis is contradictory to most of the scientific knowledge and literature regarding MUC4 contribution in epithelial cancers that is very hardly discussed in their manuscript.

MUC4 was originally identified and characterized in our laboratory [2, 3]. Research conducted in mucin laboratories around the world has clearly documented MUC4 roles in 
numerous cancers from different organs such as ovary, pancreas, oesophagus or lung. It is now established that MUC4 plays an important role in the behaviour of epithelial tumor cells. Inhibition of MUC4 expression by siRNA or stable ShRNA leads to reduced proliferation, motility, and increased cellular aggregation or chemoresistance [4-9].

Notably, MUC4 was previously suggested as an oncomucin in lung cancer. High MUC4 expression in small-sized lung adenocarcinomas correlates with a poor survival rate in a 185 patients cohort [10]. Analysis of another important cohort of 100 non-small cell lung carcinomas (NSCLCs) showed that MUC4 represses apoptosis [11]. Gao et al do not confront their results to already published literature in that matter.

The relationship between MUC4 and EMT is also conflicting since MUC4 was shown to suppress EMT in lung adenocarcinoma in the present study [1] whereas MUC4 overexpression in ovarian cancer leads to decreased expression of epithelial markers and occurrence of mesenchymal markers via upregulation of Twist1, Twist2 and Snail transcription factors and FAK signalling pathway [12]. Collectively, these results mean that MUC4 may regulate EMT in both ways.

Altogether, this clearly illustrates that caution should be kept as to using MUC4 as a marker of favourable prognosis because of the conflicting reports regarding both its involvement in tumor progression in lung cancer and more specifically in EMT and subsequent metastasis.

\section{References}

1. Gao L, Liu J, Zhang B, Zhang H, Wang D, Zhang T, Liu Y, Wang C. Functional MUC4 suppress epithelial-mesenchymal transition in lung adenocarcinoma metastasis. Tumour Biol. 2013 Sep 15.

2. Moniaux N, Nollet S, Porchet N, Degand P, Laine A, Aubert JP. Complete sequence of the human mucin MUC4: a putative cell membrane-associated mucin. Biochem J. 1999 Mar 1;338 ( Pt 2):325-33.

3. Porchet N, Nguyen VC, Dufosse J, Audie JP, Guyonnet-Duperat V, Gross MS, Denis C, Degand P, Bernheim A, Aubert JP. Molecular cloning and chromosomal localization of a novel human tracheo-bronchial mucin cDNA containing tandemly repeated sequences of 48 base pairs. Biochem Biophys Res Commun. 1991 Mar 15;175(2):414-22.

4. Bruyère $E$, Jonckheere $N$, Frenois $F$, Mariette $C$, Van Seuningen I. The MUC4 membranebound mucin regulates esophageal cancer cell proliferation and migration properties: Implication for S100A4 protein. Biochem Biophys Res Commun. 2011 Sep 23;413(2):325-9. 
5. Jonckheere N, Skrypek N, Merlin J, Dessein AF, Dumont P, Leteurtre E, Harris A, Desseyn $\mathrm{JL}$, Susini C, Frenois F, Van Seuningen I. The Mucin MUC4 and Its Membrane Partner ErbB2 Regulate Biological Properties of Human CAPAN-2 Pancreatic Cancer Cells via Different Signalling Pathways. PLoS One. 2012;7(2):e32232.

6. Kaur S, Kumar S, Momi N, Sasson AR, Batra SK. Mucins in pancreatic cancer and its microenvironment. Nat Rev Gastroenterol Hepatol. 2013 Jul 16.

7. Bafna S, Kaur S, Momi N, Batra SK. Pancreatic cancer cells resistance to gemcitabine: the role of MUC4 mucin. Br J Cancer. 2009 Oct 6;101(7):1155-61.

8. Hollingsworth MA, Swanson BJ. Mucins in cancer: protection and control of the cell surface. Nat Rev Cancer. 2004 Jan;4(1):45-60.

9. Skrypek N, Duchene B, Hebbar M, Leteurtre E, van Seuningen I, Jonckheere N. The MUC4 mucin mediates gemcitabine resistance of human pancreatic cancer cells via the Concentrative Nucleoside Transporter family. Oncogene. 2013 Mar 28;32(13):1714-23.

10. Tsutsumida H, Goto M, Kitajima S, Kubota I, Hirotsu Y, Wakimoto J, Batra SK, Imai K, Yonezawa S. MUC4 expression correlates with poor prognosis in small-sized lung adenocarcinoma. Lung Cancer. 2007 Feb;55(2):195-203.

11. Karg A, Dinc ZA, Basok O, Ucvet A. MUC4 expression and its relation to ErbB2 expression, apoptosis, proliferation, differentiation, and tumor stage in non-small cell lung cancer (NSCLC). Pathol Res Pract. 2006;202(8):577-83.

12. Ponnusamy MP, Lakshmanan I, Jain M, Das S, Chakraborty S, Dey P, Batra SK. MUC4 mucin-induced epithelial to mesenchymal transition: a novel mechanism for metastasis of human ovarian cancer cells. Oncogene. 2010 Oct 21;29(42):5741-54. 